DOI https://doi.org/10.18551/rjoas.2017-01.03

\title{
SOME ASPECTS OF RURAL-URBAN INTERDEPENDENCE: ECONOMIC-GEOGRAPHICAL VIEW
}

\author{
Rajović Goran \\ International Network Center for Fundamental and Applied Research, Russia \\ E-mail: dkgoran.rajovic@gmail.com \\ Bulatović Jelisavka \\ College of Textile Design, Technology and Management, Belgrade, Serbia \\ E-mail: jelisavka.bulatovic@gmail.com
}

\begin{abstract}
There are two broad, often overlapping, categories of rural - urban linkages. «Spatial» links refer to the movement of people, goods, money, and information between urban and rural areas. "Sectoral» links describe the interdependence between agriculture on the one hand and industry and services on the other. In the next two decades, three main issues related to rural-urban interdependence are likely to emerge: (1) changes in land use around urban centers, from farmland to residential or industrial use; (2) greater diversification of income sources in rural and urban areas, often involving people migrating or commuting between the countryside and urban centers; and (3) changes in the direction and composition of internal migration ( see Tacoli, 2000). In this text indicates on the some economic geographic aspects of rural-urban interdependence. Rural and urban development requires a balance between human capital, economic progress and natural resources. The migration of labor from rural to urban areas is an important part of the urbanization process in developing countries. Even though it has been the focus of abundant research over the past five decades, some key policy questions have not found clear answers yet. Sustainable development can be achieved at any level, provided that each component of the system to have the same importance in maintaining a balance between the need to develop and its possibilities. The rural - urban metabolism generates relations of interdependence between villages and towns, resulting in the formation of a «variety of societies, from deep rural to deep urban».
\end{abstract}

\section{KEY WORDS}

Rural, urban, interdependence, aspects.

Rural areas can be defined with respect to different aspects of rurality; namely geographic, environmental, economic, social and cultural criteria. In general, they will be different for urban and rural regions (settlement dimension), for regions with different industrial structures and different composition of the total stock of capital, including environmental resources and cultural heritage (structural dimension) (Hediger et al, 1998). Rural - urban interdependence relates to the joint or interactive relationship between urban and rural areas. The mutually are beneficial correlativeness of urban and rural areas. Traditionally, rural and urban issues and planning have been typically seen as and dealt with separately. However, in recent years as urbanization and inequality increase, more sophisticated analyses of the linkages and interdependencies between rural and urban areas have emerged (Low, et al., 1999). Urban - rural interdependence includes spatial links to the movement of people, goods, money, and information between urban and rural areas including roads and railways, and sectorial links (interdependence between agriculture, industry and services). Rural - urban interdependence is important for poverty alleviation and sustainable rural development and urbanization. Strong linkages can improve the living conditions and employment opportunities of both rural and urban populations. Domestic trade and the adequacy and efficiency of infrastructure are the backbone of mutually 
beneficial rural - urban relationships and of the success of the relationship between urban and rural areas (Bekker, 2000).

Ghiurca et al (2012) citing research Ungureanu et al (2003) and Miftode (1978) indicates that rural and urban development requires a balance between human capital, economic progress and natural resources. Sustainable development can be achieved at any level, provided that each component of the system to have the same importance in maintaining a balance between the need to develop and its possibilities. Sustainable development is a process of local importance, which involves the accumulation of wealth and the increase in the standard of living in a small space, where the natural resources and entrepreneurship plays a determinative role. The rural - urban metabolism generates relations of interdependence between villages and towns, resulting in the formation of a «variety of societies, from deep rural to deep urban».

\section{MATERIALS AND METHODS}

The presented material was mainly based on the study of many international specialty papers (see references at the end of the paper), from the observation of links between rural and urban settlements, on the occasion of documentation, as well as in consultation with numerous articles and studies published on Internet (see Chiristecu, 2011; Rajović and Bulatović, 2015; Rajović and Bulatović, 2016). A number of official websites of institutions and central and local management bodies has been taken from: OECD (1995), OECD (1998), United Nations Population Division (2005), ESPON (2009), and others.

\section{ANALYSIS AND DISCUSSION}

To make an accurate analysis of what is rural, with all its characteristic elements, we cannot differentiate rural areas from urban ones. Most often, rural interacts with urban space. Knowledge of rural, in all its dimensions, requires, in many respects, a comparative «rural urban» analysis. Differences between rural and urban areas, in terms of economic and social organization, and also development issues are the result of the «rural-urban» distinction. Views on the conduct of the relationship are shared (Furdui et al, 2011). For example, according to Furdui et al (2011) citing research Badouin (1971) defines rural as opposed to urban areas, designating through this concept ... popular areas characterized by a relatively weak density and prevalence of agricultural activities. Rural areas, unlike urban space, do not imply strong concentrations of people. Clusters are limited to the size of the village. It is represented by a form of scattered habitat in the form of hamlets or farms disseminated in nature. Rural areas are suitable for agricultural activities ... On the other hand; if rural space favors land as a production factor ... rural area is simultaneously settlement and environment. On the other hand, Meves (1981) by Furdui et al (2011) trying to rekindle the interference between rural-urban terms, explains that this relationship tends to integrate in both ways: urban in rural and contrary. In addition, the author makes a reference to agriculture as plant and animal production process that although plays a determinant role, the phenomenon is only part of agriculture it is inextricably linked to the rural environment but not necessarily to the urban one. Solutions regarding how to establish the new urban - rural linkages are based on the availability of public transport and services, cooperation among urban and rural areas, the inclusion of suburban territories in spatial planning strategies, as well as the formation of networks of small and medium enterprises in provincial towns and rural areas. A more are detailed summary of goals, instruments, and gains in presented in Figure 1 (Bulderberga, 2011). 


\begin{tabular}{|c|c|c|}
\hline $\begin{array}{l}\qquad \frac{\text { GOALS }}{\text { Providing local services and }} \\
\text { public transport }\end{array}$ & $\begin{array}{l}\quad \text { INSTRUMENTS } \\
\text { Land-use planning, service } \\
\text { provision and infrastructure }\end{array}$ & $\begin{array}{l}\text { RATIONALE } \\
\text { Promoting accessibility }\end{array}$ \\
\hline $\begin{array}{l}\text { Improving co-operation } \\
\text { between urban and rural } \\
\text { authorities }\end{array}$ & Joint planning & $\begin{array}{l}\text { Strengthening functional } \\
\text { regions }\end{array}$ \\
\hline $\begin{array}{l}\text { Integrated urban and rural } \\
\text { planning }\end{array}$ & Spatial strategies & Improving quality of life \\
\hline $\begin{array}{l}\text { Co-operation between small } \\
\text { and medium towns }\end{array}$ & $\begin{array}{l}\text { Partnerships, joint projects, } \\
\text { exchange of experience }\end{array}$ & $\begin{array}{l}\text { Promoting innovation and } \\
\text { competitiveness }\end{array}$ \\
\hline $\begin{array}{l}\text { Networking between } \\
\text { enterprises in urban and rural } \\
\text { areas }\end{array}$ & $\begin{array}{l}\text { Partnerships, joint projects, } \\
\text { exchange of experience }\end{array}$ & Promoting competitiveness \\
\hline
\end{tabular}

Figure 1 - Policy directions on rural - urban partnership (Bulderberga, 2011)

The United Nations reports that 43 percent of the world's population lived in urban areas in 1990; a 34 percent increase since 1960. In 2005 the world will pass a historic milestone: more than half of its population - or more than three billion people - will live in cities ( see OECD,1995; OECD, 1998; United Nations Population Division, 2005; ESPON, 2009). At the turn of the century, only 14 percent of the Earth's population called cities home - and just 11 centers on the planet had more than one million inhabitants. At the halfway mark of the 21st Century, more than 70 percent of the world's population will live within the metropolitan framework (an area now loosely defined up to 40 - 100 kilometers from the older urban cores). In most more developed nations, especially in North America and Europe, the urban - rural distribution now stands at 75 - 80 percent metropolitan to 20 - 25 percent rural (Keler, 2001). Mylott (2009) citing research Tacoli (1998), Tacoli (1998), Tacoli (2003) and Rosenthal (2000) indicates that ural - urban linkages are important for poverty alleviation and sustainable rural development and urbanization. By Saracoglu and Roe (2004) citing research Ammassari (1994), Tabuchi et al (2002), Mazumdar (1987), HarrisTodaro (1970), Gupta (1997), Basu (2000), Bhattacharya (2002) indicates that rural-urban migration, or internal migration, is in essence a change in the spatial distribution of population in a given country over time. Migration and the change in population distribution are influenced by specific characteristics of the economic development process and by various stages of development in a country. Migration has been seen as a response of individuals to better economic and non - economic opportunities and an expectation of increased economic welfare in urban areas. Migrants are attracted to the cities with the expectation of a higher wage than they receive in agriculture, and are willing to accept the probability of urban unemployment, or lower wages and "underemployment» in the urban informal (traditional) sector. Migrant is willing to accept urban unemployment or lower wages in the urban informal sector as long as he expects to "graduate» to the urban modern sector in the future. Further regional heterogeneity may arise due to the existence of regional non traded goods, which exacerbates the differences in cost of living across regions. For an individual to be in equilibrium (i.e. no migration), it must be the case that his expected utility derived from staying in the rural region is equal to the expected utility derived by moving to the urban region. Since the household's income and consumer prices in a region directly affect the consumption decision, they also affect the household's expected utility from staying or migrating... ( see Saracoglu and Roe, 2004). The increasingly complex connections between urban and rural areas are beginning to be recognized but «still have a relatively limited impact on development policy and practices. The regional development planning used 
to create a better balance between urban and rural and reduce migration pressure on urban areas has disproportionally benefitted large farms and wealthy land owners. Even many policies that attempt to draw on urban - rural linkages are often unsuccessful because they fail to reflect the true circumstances of the people they are created to help.

It is clear that the study of internal migration suffers from a lack of appropriate datasets. Future research will be much improved if it can: (1) Better characterize internal migration flows and stocks. It would be very useful to have databases on internal migration by education in a selection of developing countries, complementing the work of Docquier and Marfouk (2005) who recently built such a database for international migration. This would enable researchers to compare the phases of the urbanization and migration process across countries, which is crucial since policy recommendations can differ according to the context ( Lall et al,2006); (2) Use panel micro datasets. This will help address several standard econometric problems, as well as improve the economic understanding of a process which takes time and whose effects are spread out over time. For instance, with such data, duration models could be tested to study the employment and unemployment spells of workers following migration. It would also be highly desirable for researchers to have access to datasets incorporating an economically relevant and sufficiently fine spatial identifier that would enable researchers to better study the workings of local labor markets (since interactions probably occur at a small geographic level). Such data would also enable the matching of different sources and enable researchers to better take into account the local contexts of both origin and destination areas. In this respect, surveys with information on both areas of origin and areas of destination (for instance village studies matched with a sample of migrants originating from the area) should prove very useful. Building such datasets is costly but it is important to gain a sufficiently fine understanding of the migration process to make it beneficial (Lall et al, 2006).

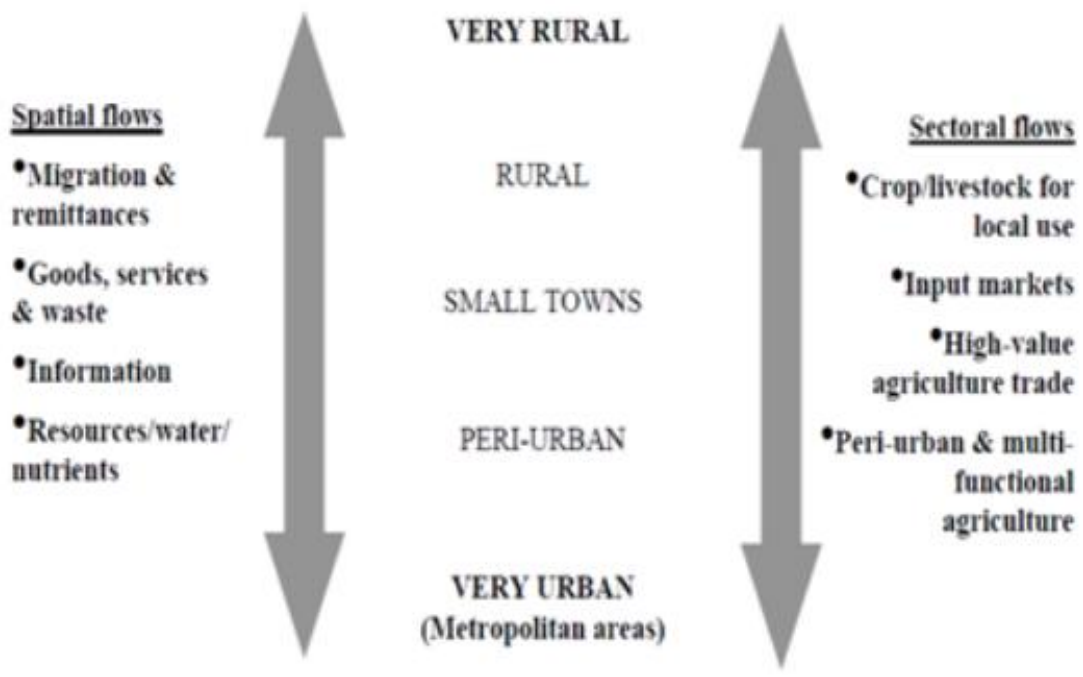

Figure 2 - Howls flows between rural and urban areas (Kasanoff, 2014)

Understanding rural - urban linkages matters because it provides the basis for measures that can improve both urban and rural livelihoods and environments. Ignoring them means that important opportunities will be lost, and in many cases it will also contribute to poor and marginal people's hardship. There are urban initiatives that can reduce ecological damage to rural areas, and help support regional development. Solutions to urban stretch are to promote squeezed land use and strategic transport planning at a neighborhood level (Kasanoff, 2014).The other option is to strengthen links between peripheral parts of a region such as positive development in small and medium size cities of a region. In this way they can offer a better environmental quality and better local public services. Also with this Urban - rural co-operation on sustainable energy projects is likely to make a greater and positive 
impact. Local government and other local actors are best placed to identify local needs and priorities and provide an adequate response. Local decision-making can help avoid the neglect of forward and backward linkages between two domains. It can also negotiate and regulate the use of natural resources by rural and urban residents, which can otherwise become a major cause for conflict (Kasanoff, 2014).

According to Steinberg (2014) key message and underlying issues: urbanization is irreversible and so is the urbanization of rural hinterlands. Today, rural hinterlands and urban areas are becoming more linked than ever. The nature of linkages has changed from a separation and dichotomy towards close linkages between the two spheres towards more integrated systems, a rural system and an urban system which are closely linked through the flow of people, production, commodities, capital and income, information, natural resources, waste and pollution. This existence of reciprocal rural - urban linkages proves to be highly relevant to interpret development of both rural and urban contexts as two sides of the same coin, so to speak. Cities should be seen as engines of rural development, providing markets and infrastructure, as well as a range of essential services, for the productivity of rural activities ( see Figure 3).

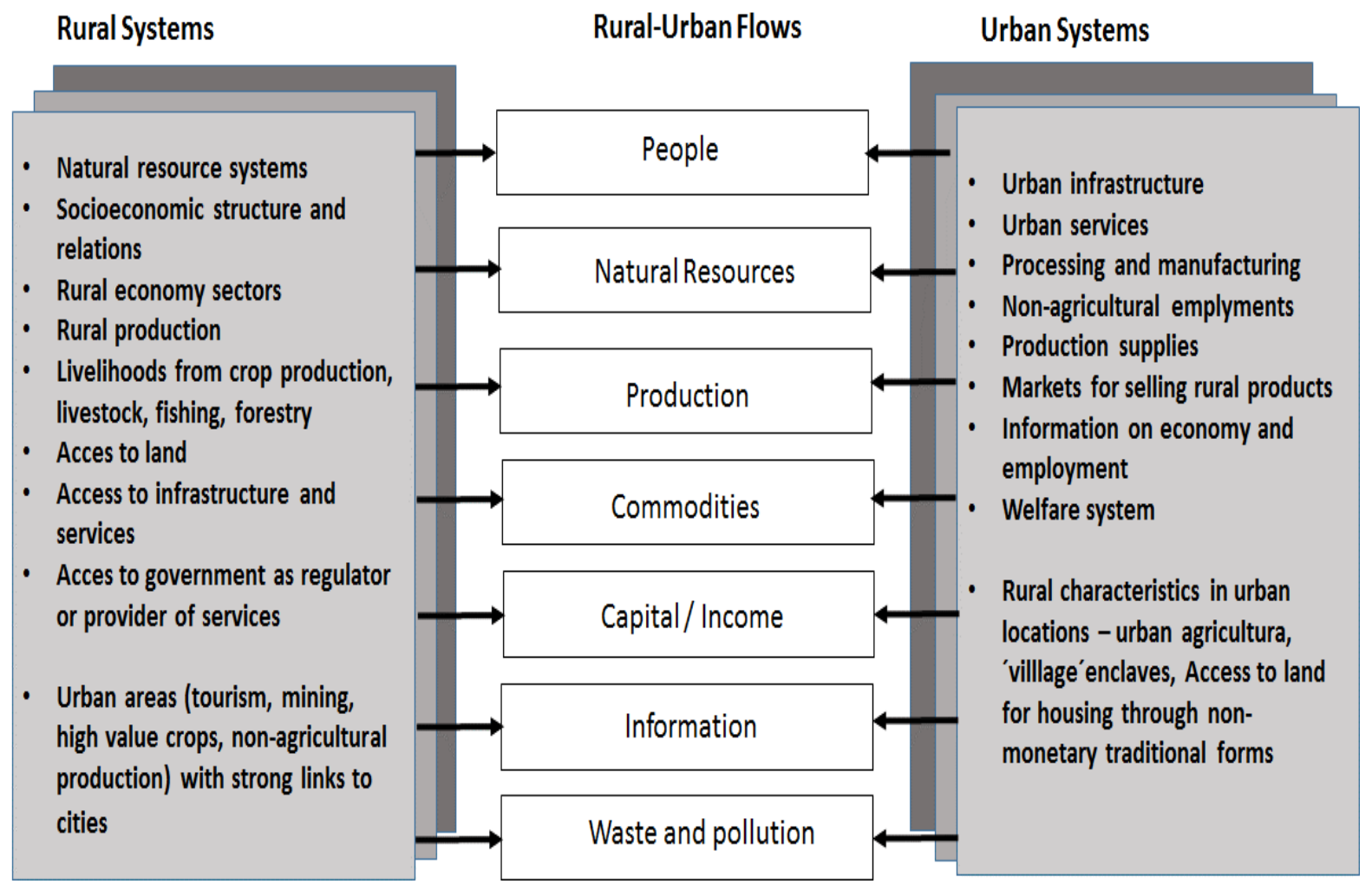

Figure 3 - Rural - Urban Flows (Steinberg, 2014), according to Douglass (1998)

Urban Functions in Rural Development (UFRD) is based on the concept that rural towns could mediate between the big 'parasitic' cities and agricultural areas and facilitate the commercialization of agriculture (Johnson and Rasker, 1970). According to Mulongo et al (2010) citing research Douglass (1998) ) indicates that the towns in this network have been expected to serve as centres of information and knowledge, infrastructure, and as central places for marketing production and purchasing supplies, and non-agricultural employment for rural labour. This approach was applied in selected number of developing countries but has shown limited success in promoting rural development and stemming rural to urban migration. „Empirical studies have highlighted three very instructional conceptual and practical limitations with this approach: (1) The economic activities and needs of rural areas are not prescribed by the nature of rural town. Rather it is the other way around- the 
characteristics and functions of rural towns vary with the types of economic activities in a rural area. Therefore, attempts to promote desirable rural benefits by establishing a hierarchy of towns with predetermined functions generally fail. It is necessary to carefully determine the existing systems of production functions of rural towns and specific rural and urban linkages, and not assume that the benefits of the network strategy will always be relevant and beneficial Consumption by rural people is not limited by lack of access to goods. It is limited to incomes (Improved access to infrastructure and greater efficiency of product and inputs and products, in the absence of viable capital injections, many towns in developing countries have not become dynamic "service centres»; (2) Interaction in rural towns and diffused urban centres does not usually include the poorest of the poor. They often lack the necessary resource to move extensively over space and to access the advantages, such as non-farm employment of towns. Therefore, even if the UFRD approach were fully successful in all other respect, it would not address rural poverty without more specific attention to the rural economy and needs of the poor» (Mulongo et al, 2010).

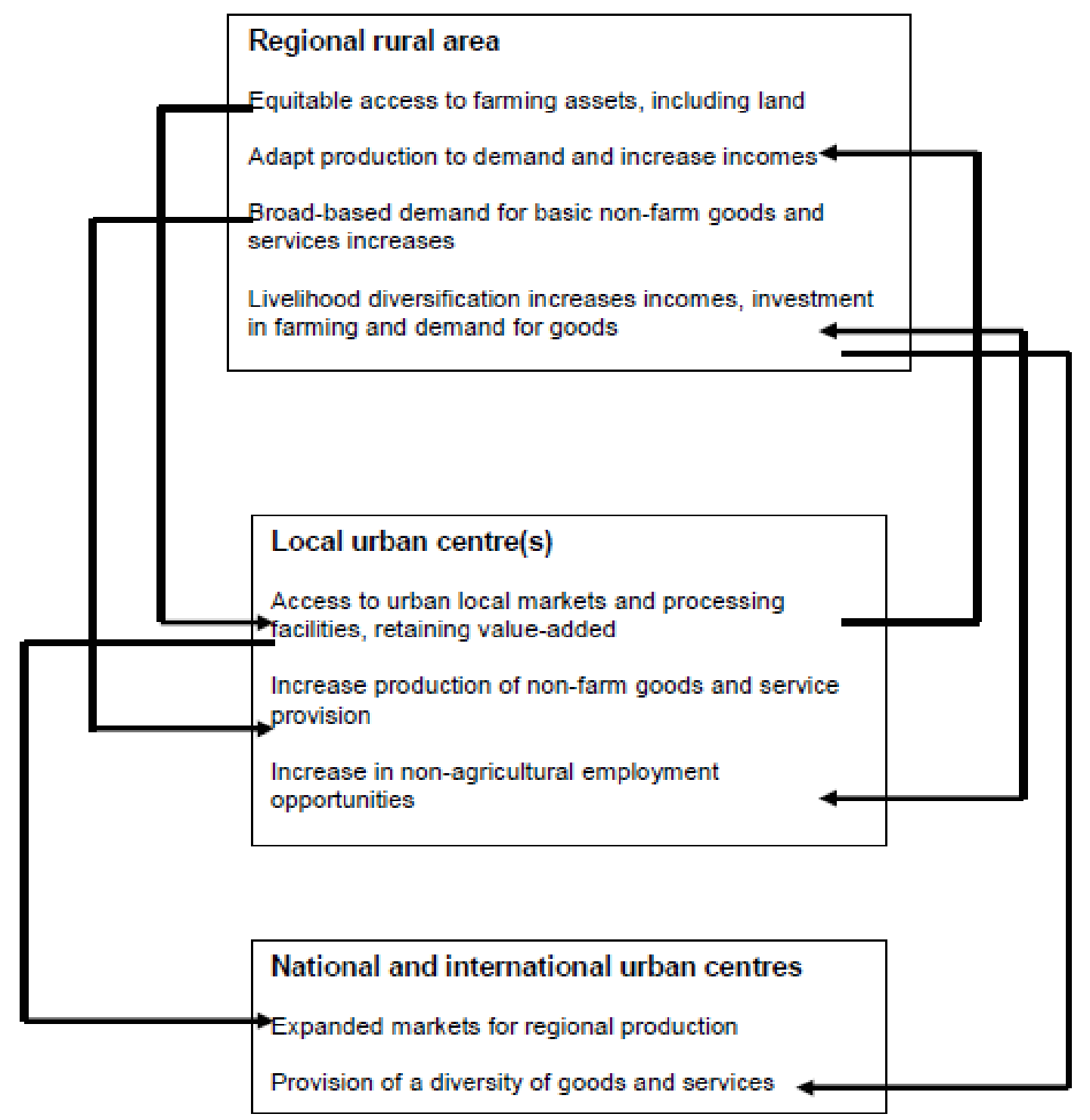

Figure 4 - Positive rural - urban interactions and regional development (Tacoli, 2004)

According to Cattaneo et al (2016) citing research Zeleny (1982), Kaiser et al (1995), Steiner (2000) indicates that territorial issues and problems involve different disciplines and scales; the managing of such problems require a well defined logical framework. Considering 
the iterative nature of planning processes and the complex nature of urban and rural, it is extremely difficult to describe the non - linear relations among the multitude of entities that must be organized. In itself, the complexity implies the inability to fully describe the behavior of a given system using a single model or a finite set of models: it is necessary multidisciplinary, dynamic, flexible and adaptive tools and it is crucial the role of integrated assessments as a tool to support the planning and decision-making process. In this perspective, it is possible to use tools to develop Multicriteria Decision Support System (MCDSS).

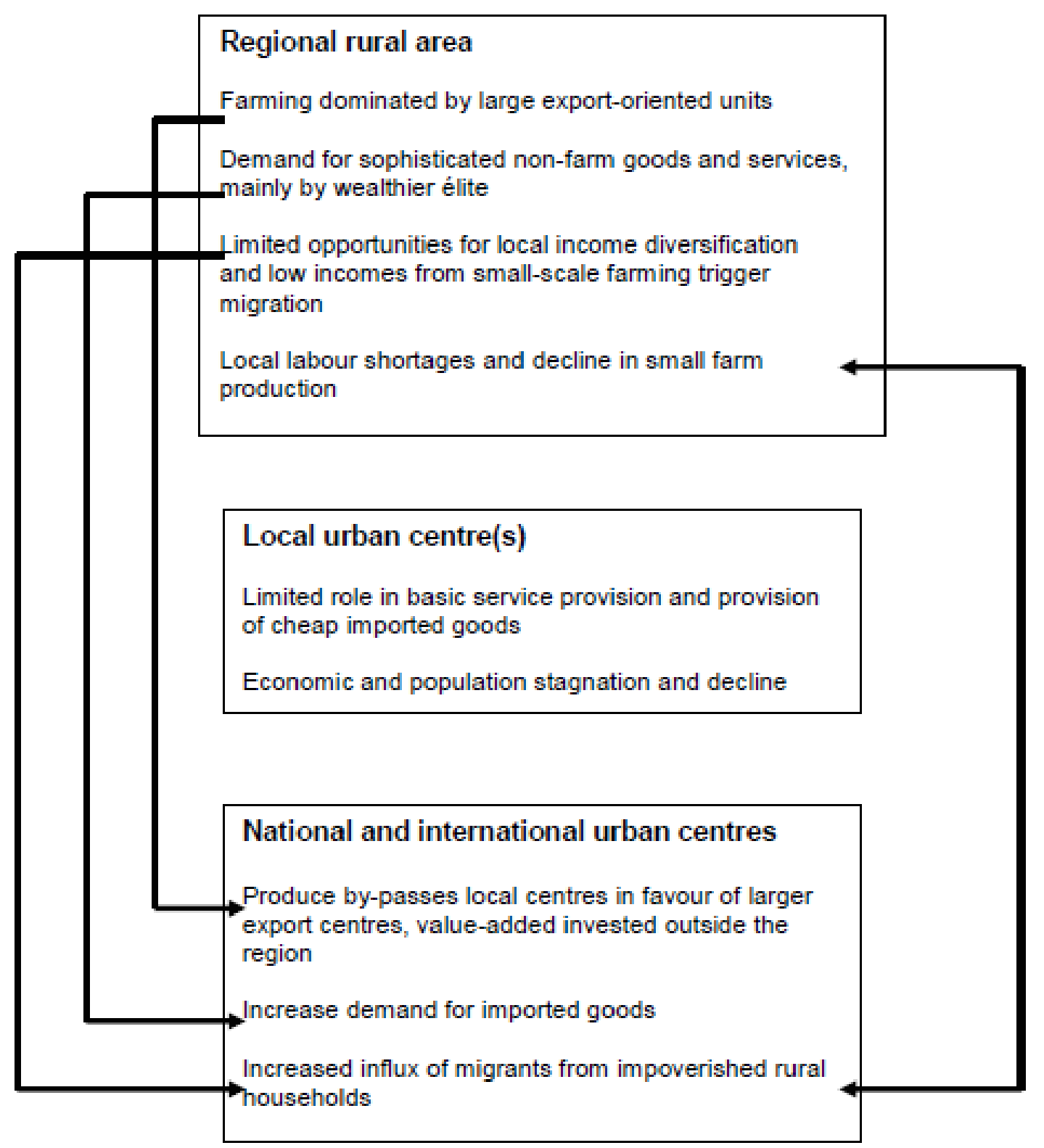

Figure 5 - Negative rural - urban interactions and regional development (Tacoli, 2004)

International context: access to international markets for small and medium-sized producers, with stable commodities prices. Foreign investment supports local production; imports do not compete with locally produced goods. National context: equitable distribution of and access to land; regionally balanced growth strategies including satisfactory provision of infrastructure, credit facilities for small and medium-sized producers, and basic services (education, health, water and sanitation); revenue support to local government; regulated 
institutional structure of markets. Local governance: accountable, with adequate resources and capacity; identifies local needs and priorities and responds to them; supports forward and backward linkages between agriculture and services and industry located in local urban centres; regulates local natural resource management; integrated with national planning (Tacoli, 2004).

International context: limited access to international markets for small and mediumsized producers, unstable commodities prices; foreign investment concentrates in large-scale export production, imports compete with locally produced goods. National context: inequitable distribution of and access to land; regionally imbalanced growth strategies including limited provision of infrastructure, credit facilities for small and medium-sized producers, and basic services (education, health, water and sanitation); lack of support to local government; unregulated institutional structure of markets. Local governance: unaccountable, with inadequate resources and capacity; not integrated with national planning (Tacoli, 2004).

\section{CONCLUSION}

In the 1950s, communities (urban and rural) according to Patrick (2010) citing research Uhl and Rossmiller (1964) and Bradshaw (2000) indicates that were seen to be detached from their neighbors. The economies of rural and urban communities were separate and distinct. However, in the 21st century, new technologies and transportation innovations have changed these circumstances. The reason is that, benefits of such interrelationships far outweigh any purported competition especially when considered from economies of scale principles in terms of integrated planning approach by urban and rural societies. Associated with the changing rural -urban relationship are improvement in transportation and communications, higher educational attainment, and common social activities (see Stauber, 2001; Isserman, 2005). In developing economies, structural changes often have profound spatial implications.

Lall et al (2006) focuses on labor-related migration from rural to urban areas, a general pattern which plays a central role in the urbanization process and is often viewed as the labor market adjustment to the inter sectoral shift in importance from agriculture to manufacturing and services. Rural to urban migration has historically been an important part of the urbanization process and continues to be significant in scale, even though migration rates appear to have slowed down in some countries. However, in spite of five decades of abundant research, some key policy questions have not found clear answers yet: (1) To what extent is internal migration a desirable phenomenon and under what circumstances?; (2) Should governments intervene and if so with what types of interventions? And (3) For the latter, what should be the policy objectives?. Answering these questions is not easy given that internal migration may have both positive and negative implications. On the one hand, internal migration is a prerequisite for urbanization, a phenomenon whose role has long been recognized as the key correlate accompanying economic growth, at least in the case of European cities in the 19th and early 20th centuries ( see Todaro, 1976; Bhatia, 1979; Mohtadi, 1986; Taylor and Adelman,1996; De Haan and Rogaly, 2002; Kochar, 2004).

Rural - urban linkages include flows of agricultural and other commodities from rural based producers to urban markets, both for local consumers and for forwarding to regional, national and international markets; and, in the opposite direction, flows of manufactured and imported goods from urban centers to rural settlements (see Masduqi et al, 2010; Leonard et al, 2011; Chandy et al, 2014). They also include flows of people moving between rural and urban settlements, either commuting on a regular basis, for occasional visits to urban - based services and administrative centers, or migrating temporarily or permanently. Flows of information between rural and urban areas include information on market mechanisms - from price fluctuations to consumer preferences - and information on employment opportunities for potential migrants. Financial flows include, primarily, remittances from migrants to relatives and communities in sending areas, and transfers such as pensions to migrants returning to 
their rural homes, and also investments and credit from urban - based institutions ( Tacoli, 2004).

By Dabson (2007) Garrett (2005) suggests the need for new language and new typologies to distinguish differences in livelihood strategies and conditions within urban and rural areas as well as between them. He argues that there needs to be more focus on «systems» and less on «sectors,» paying more attention to economic activity and urban rural integration within regional economies. Such a regional approach would provide the context for thinking more holistically about the roles that areas along the rural-urban spectrum can play. He concludes: Holding up a rural - urban lens to development is useful for illuminating new ways of thinking about development strategies and about urban and rural transformations, particularly as urbanization and migration continue, as rural livelihoods diversify, and as the agriculture and food system becomes more complex. Both rural and urban livelihoods can benefit from this perspective, but only if it leads to improved and closer interactions, not continued separations in mindsets, policies, and institutions.

Rural and urban development in sustainable context is a complex process that requires an improvement of the existing situation and a removing of the dysfunctions. Over time, the rural area was not addressed as much as urban area, rural analysis is often fragmentary explained and incomplete argued. The system of values owned by rural area is overshadowed by an economic, social and cultural subordination to the city. The connection that is established is a support for the systems analysis of settlements and is the consequence of the functional differentiation between cities and villages, evidenced by the natural, social and economic aspects representative for each system (Ghiurca et al,2012).

\section{REFERENCES}

1. Tacoli, C. (2000). Rural - Urban Interdependence. Available from: https //www.nzdl.org (17.09 2016).

2. Hediger, W., Theler, A. D., Lehmann, B. (1998). Sustainable Development of Rural Areas - Methodological Issues, pp. 1 - 20, 38. Congress of the European Regional Science Association 28 Avgust - 01 September in Vienna.

3. Low, B., Costanza R., Ostrom E, Wilson J., Simon, C.P. (1999). Human's ecosystem interactions: a dynamic integrated model. Ecological Economics, Vol. 31, pp. 227 - 242.

4. Bekker, S. (2000). Internal migration and infrastructural provision: challenges to inter provincial planning in South Africa, Symposium on Challenges for Integrated Rural Development. Cape Town: University of Cape Town Press.

5. Ghiurca, A., Lamasanu, A., Mihai, F. C. (2012). Rural - urban relations in the context of sustainable development. Case Study: Cuejdiu Valley Basin, Neamt County. Case Study: Cuejdiu Valley Basin, Neamt County. Vol. pp. 327 - 330.

6. Ungureanu, I., Muntele, I., Dragu, V., Gheorghiţă, C. (2003). Geografia mediului. Omul şi natura la început de mileniu. Institutul European laşi, pp.107.

7. Miftode, V. (1978). Migraţiile şi dezvoltarea urbană. Editura Junimea, laşi, pp.16.

8. Chiritescu, V. (2011). Sustainable Rural Development in Romania - Needs and Priority Objectives. Agricultural Economics and Rural Development. Vol.1, No.1, pp. 147 - 160.

9. Rajović, G., Bulatović,J. (2015). Rural Society of Montenegro in the past and the future, «Anthropogenic evolution of modern soils and food production under changing of soil and climatic conditions», October 29 - November 28, pp. 85 - 87. Proceedings of International Scientific and Practical E - Conference on Agriculture and Food Security. Orel State Agrarian University, All-Russian Institute of Phytopathology, Gorsky State Agrarian University. Russian Federation.

10. Rajović,G., Bulatović,J. (2016). Rural Roads - Issues and Development: Overview. UCT Journal of Management and Accounting Studies. Vol. 4, No. 4, pp. 76 - 85.

11. OECD (1995). OECD Reviews of Rural Police: Switzerland, OCDE/GD (95) 103. Territorial Development Service, Rural Development Programme. OECD, Paris. 
12. OECD (1998). Agricultural Policy Reform and the Rural Economy in OECD Countries. OECD, Paris.

13. United Nations Population Division (2005). World Urbanization Prospects: The 2005 Revision, New York and Geneva.

14. ESPON (2009). EDORA (European Development Opportunities for Rural Areas) Applied Research Project 2013/1/2. Version 3 300409. Interim Report.

15. Furdui, L. M., Pruteanu, E. M., Serbu, M. V. (2011). Dynamics of Rural - Urban Relations in Urbanization Context. Economia. Seria Management. Vol. 14, No. 2, pp. 484 - 491.

16. Badouin, R. (1971). Economie Rurală. Editura Armand Colin. Bucharest.

17. Meves, E., (1981), Relaţia Agrar - Agricol - Rural, EdituraTerra Nostra, Bucharest.

18. Bulderberga, Z. (2011). Rural - urban partnership for regional development. Socialiniai tyrimai/Social Research. Vol. 1, No 22, pp. 14 - 24.

19. Keller, J. (2001). The importance of rural development in the $21^{\text {st }}$ - century: Persistence, sustainability and futures. The future of Australia's country towns, pp. $19-31$.

20. Mylott, E. (2009). Urban - rural connections: a review of the literature. Scholars Archive@ OSU, Papers (Rural - Urban Connections).

21. Tacoli, C. (1998). Rural - urban interactions; a guide to the literature. Environment and urbanization. Vol. 10, pp. $147-166$.

22. Tacoli, C. (1998). Bridging the divide: rural - urban interactions and livelihood strategies (pp. 98 -101), International institute for environment and development (IIED). Sustainable agriculture and rural livelihoods programmed.

23. Rosenthal, T. C. (2000). Outcomes of rural training tracks: a review. The Journal of Rural Health. Vol. 16, No. 3, pp. 213 - 216.

24. Saracoglu, D. Ş., Roe, T. L. (2004). Rural - urban migration and economic growth in developing countries. In Society for Economic Dynamics 2004 Meeting Paper. Vol. 241, pp. 1 - 32.

25. Ammassari, S. (1994). Internal Migration, Population Distribution and Development Policy. Institute of Development Studies Discussion Paper No. 342.

26. Tabuchi, T., Thisse, F. J. (2002). Taste heterogeneity, labor mobility and economic geography. Journal of Development Economics. Vol. 69, pp. 155 -177.

27. Mazumdar, D. (1987). Rural - urban migration in developing countries' in Handbook of Regional and Urban Economics. Volume II. Edited by E.S. Mills. Elsevier Science Publishers.

28. Harris, J.R., Todaro, P.M. (1970). Migration, unemployment and development: A twosector analysis. American Economic Review. Vol. 60, pp. $126-142$.

29. Gupta, M.R. (1997). Informal sector and informal capital market in a small-open lessdeveloped economy. Journal of Development Economics. Vol. 52, pp. 409 - 428.

30. Basu, B. (2000). Rural - Urban Migration, Urban Unemployment and the Structural Transformation of a Dual Economy. Journal of International Trade and Economic Development. Vol. 9, No. 2, pp. 137 - 49.

31. Bencivenga, V.R., Smith,D.B. (1997). Unemployment, Migration, and Growth. The Journal of Political Economy. Vol. 105, No. 3, pp. 582 - 608.

32. Lall, S. V., Selod, H., Shalizi, Z. (2006). Rural - urban migration in developing countries: A survey of theoretical predictions and empirical findings. World bank policy research working paper. Vol. 3915, pp. 1 - 63.

33. Docquier F., Marfouk, A. (2005). International migration by education attainment 1990 2000. In International Migration, Remittances and the Brain Drain. Ozden and Schiff eds., the World Bank and Palgrave Macmillan, pp. 151-99.

34. Kasanoff, B. (2014). Environmental Implication of rural urban linkages. Available from: https://www.linkedin.com (18.09 2016).

35. Steinberg, F. (2014). Rural - Urban Linkages: an urban perspective, Working paper prepared for Rimisp as a contribution to a Desktop Review on Inclusive Rural - Urban Linkages commissioned by The Ford Foundation. 
36. Douglass, M. (1998). A regional network strategy for reciprocal rural - urban linkages: an agenda for policy research with reference to Indonesia. Third World Planning Review. Vol. 20, No.1, pp. 1 - 35.

37. Johnson, J. D., Rasker, R. (1995). The role of economic and quality of life values in rural business location. Journal of Rural Studies. Vol. 11, No. 4, pp. 405 - 416.

38. Mulongo, L. S., Erute, B. E., Kerre, P. M. (2010). Rural - Urban Interlink and Sustainability of Urban Centers in Kenya; A case of Malaba Town. pp. $1-16.46$ th ISOCARP Congress 2010. Nairobi, Kenya.

39. Cattaneo, T., De Lotto, R., Venco, E. M. (2016). Functional Reuse and Intensification of Rural - Urban Context: Rural Architectural Urbanism. International Journal of Agricultural and Environmental Information Systems (IJAEIS). Vol. 7, No.1, pp. 1-27.

40. Zeleny, M. (1982). Multiple criteria decision making. New York: McGraw - Hill.

41. Kaiser, E. J. et al. (1995). Urban Land Use Planning. 4th edition. Urbana, IL: University of Illinois Press.

42. Steiner, F. (2000). The Living Landscape: An Ecological Approach to Landscape Planning. 2nd Ed. New York: McGraw - Hill.

43. Tacoli,C. (2004). Rural - Urban Linkages and Pro-Poor Agricultural Growth: An Overview, Prepared for OECD DAC POVNET Agriculture and Pro - Poor Growth Task Team Helsinki Workshop. pp. 14 - 15, 17-18 June.

44. Patrick, T. (2010). The evolving rural and urban interdependence: Opportunities and challenges for community economic development. Journal of Geography and Regional Planning. Vol. 3, No. 12, pp. 339 - 345.

45. Uhl, J.N., Rossmiller, G.E. (1964). Rural - Urban Research and Extension Programs: An Integrated Proposal. J. Farm Econ. Vol. 46, No. 5, pp. 1032 -1036.

46. Bradshaw, T.K. (2000). Complex Community Development Projects: Collaboration, Comprehensive Programs, and Community Coalitions in Complex Society. Community Dev. J. Vol. 35, No. 2, pp. $133-145$.

47. Stauber, K. (2001). Why Invest in Rural America - And How? A Critical Public Policy Question for the 21st Century. In Center for the Study of Rural America, Exploring Policy Options for a New Rural America. Kansas City, MO: Federal Reserve Bank of Kansas City.

48. Masduqi, A., Endah, N., Soedjono, E. S., Hadi, W. (2010). Structural equation modeling for assessing of the sustainability of rural water supply systems. Water Science and Technology: Water Supply. Vol. 10, No. 5, pp. 815 - 823.

49. Leonard, M. S., Kerre, P. M., Boniface, E. E. (2011). Rural - urban interlink and sustainability of urban centres in Kenya: a case of Malaba Town. Journal of US - China Public Administration. Vol. 8, No. 8, pp. 871 - 883.

50. Chandy, T., Keenan, R. J., Petheram, R. J., Shepherd, P. (2012). Impacts of hydropower development on rural livelihood sustainability in Sikkim, India: Community perceptions. Mountain Research and Development. Vol. 32, No. 2, pp. 117-125.

51. Isserman, A.M. (2005). In the National Interest: Defining Rural and Urban Correctly in Research and Public Policy. Int. Regional Sci. Rev. Vol. 28, pp. 465 - 499.

52. Todaro, M. (1976). Urban job expansion, induced migration and rising unemployment: A formulation and simplified empirical test for LDCs. Journal of Development Economics. Vol. 3, pp. 211 - 225.

53. Bhatia, K. (1979). Rural-urban migration and surplus labour. Oxford Econ. Papers. pp. 31.

54. Mohtadi, H. (1986). Rural stratification, rural to urban migration, and urban inequality. World Development. Vol. 14, pp. 713 - 25.

55. Taylor, J., Adelman, I. (1996). Village economies - The design, estimation, and use o village - wide economic models. Cambridge: Canbridge University Press.

56. De Haan, A., Rogaly, B. (2002). Migrant workers and their role in rural change. Journal of Development Studies. Vol. 38, No. 5, pp. 1 - 14. 
57. Kochar, A. (2004). Urban influences on rural schooling in India. Journal of Development Economics. Vol. 74, pp. 113 - 36.

58. Dabson, B. (2007). Rural - urban interdependence: Why metropolitan and rural America need each other. A Background Paper Prepared for the Blueprint for American Prosperity Metropolitan Policy Program at Brookings.

59. Garrett, J. (2005). Beyond Rural Urban: Keeping up with Changing Realities. Washington: International Food Policy Research Institute. 